Abstract

\title{
Analysis of the Cytotoxic Effects of Achillea millefolium L. Extracts on MCF7 Cell Line ${ }^{\dagger}$
}

\author{
Esra Köngül *, Ömer Taş, Leyla Paşayeva and Gökçe Şeker Karatoprak \\ Department of Pharmacognosy, Faculty of Pharmacy, Erciyes University, Kayseri 38039, Turkey \\ * Correspondence: eczesr@gmail.com; Tel.: +90-352-207-6666-28178 \\ + Presented at the 2nd International Conference on Natural Products for Cancer Prevention and Therapy, \\ Kayseri, Turkey, 8-11 November 2017.
}

Published: 13 November 2017

\begin{abstract}
Achillea millefolium L. an herbaceous perennial plant from Asteraceae family which has antitumor, anti-inflammatory and antioxidant activity. Breast cancer is the most common cancer in woman. Therefore, in this study we aimed to investigate the effects of the different extracts of $A$. millefolium on breast cancer with in vitro cytotoxicity assay. Within the scope of this study, the compositions of extracts prepared with water, 30\% ethanol, 60\% ethanol, 90\% ethanol and absolute ethanol obtained from the above-ground parts of A. millefolium, was investigated by Folin-Ciocalteu method for total phenolics, $\mathrm{AlCl}_{3}$ colorimetric method for total flavonoid content. Cytotoxic effects on MCF7 (human breast cancer cell line) cell line were studied with MTT assay. It has been elucidated that $60 \%$ ethanol extract is rich in total phenolics content and $90 \%$ ethanol extract is rich in total flavonoid content. Water extract was found to be most cytotoxic extract with $30.67 \pm 2.27$ $\mu \mathrm{g} / \mathrm{mL} \mathrm{IC}_{50}$ value on MCF7 cell line.
\end{abstract}

Keywords: Asteraceae; Achillea millefolium; cytotoxicity; MCF7; MTT

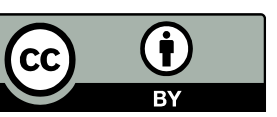

(C) 2017 by the authors. Licensee MDPI, Basel, Switzerland. This article is an open access article distributed under the terms and conditions of the Creative Commons Attribution (CC BY) license (http://creativecommons.org/licenses/by/4.0/). 